\title{
Modeling the Relationship Between Risks and the Sustainability of Microfinance Institutions (MFIs) in Ghana
}

\author{
Joseph M. Boadi $^{1^{*}} \quad$ Francis K. Bondinuba ${ }^{2} \quad$ Alex L. Eyiah ${ }^{3} \quad$ DeGraft Owusu-Manu ${ }^{4}$ \\ 1 .Institute of Distance Learning, Kwame Nkrumah University of Science and Technology, Ghana. \\ 2. Department of Building Technology, Kumasi Technical University, Ghana. \\ 3. Department of Built Environment, Pentecost University College, Accra, Ghana \\ 4. Department of Building Technology, Kwame Nkrumah University of Science and Technology, Ghana.
}

\begin{abstract}
A number of Microfinance Institutions (MFIs) both in Ghana and in other countries have had risk-related challenges that have affected their sustainability. In recent years, strategic decisions of risk have affected MFIs operations in Ghana significantly. This paper seeks to demonstrate the relationship between risk factors and MFIs sustainability in Ghana. The paper adopts a quantitative strategy for the data source with a deductive approach. The hypothesis carried out on various drivers of sustainability were upheld with a significant p-value of $0.000<$ $0.01 \mathrm{p}$ and concluded that all the drivers of sustainability identified have a significant effect on MFIs sustainability in Ghana. The measurement model and structural model of the Partial Least Square Structural Equation Model (PLS-SEM) was used to measure the relationship between risk and MFIs sustainability. The path coefficient between risk factors and the drivers of MFIs sustainability was 0.582 with a significant $p$-value of $0.000<0.01$. This establishes that risk factors have a significant effect on all drivers of microfinance institutions sustainability. Operators of microfinance in Ghana need to take an appreciable and well-managed level of risk to enhance their sustainability.
\end{abstract}

Keywords: institutions, microfinance, risk, sustainability

DOI: $10.7176 / \mathrm{JESD} / 10-12-11$

Publication date:June $30^{\text {th }} 2019$

Microfinance Institutions (MFIs) have been part of the financial sector in Ghana and are making a significant impact on the low-income earners and the rural poor. Their operation promotes economic development, job creation, and poverty alleviation. However, their sustainability is been hampered by various risk factors that are confronting the industry. Economists Frank Knight in 1921 refers to risk as situations in which the outcome is not certain, but where the likelihoods of the substitutes are known (Moore, 1970. Risk in microfinance is defined broadly as any potential event or an on-going trend which can cause future losses or declines in future income of an MFI (Fernando, 2008). Events or on-going trends are risk factors. Some of the identified risk factors in other research works are an operational risk, financial management risk, credit risk, liquidity risk, governance risk, to mention a few. On the other hand, sustainability according to Kibert et al (2012) can be referred to as the ability to recap performance through time and it is imperative that MFIs remains sustainable to help the poor and the lowincome earner.

The study seeks to find if there is an existing relationship between risk factors and MFIs sustainability in Ghana. Uyemura et al., (1993) emphasized the importance of risk on microfinance institutions sustainability and recommended that management should view risk as to the fundamental norm that much attention should be focused on, considering the future uncertainties.

Labie (2001) attributed some challenges and collapse of most MFIs to deficiencies in financial management skills, knowledge and abilities to perform effectively. Like any other MFIs in the world, Ghanaian MFIs do not aspire to corporate governance best practices. Boateng et al., (2014) made it clear that corporate governance is a basic component of risk management but not entirely constituents to organizational success.

Robinson (2003) and Ledgerwood (1999) also mentioned liquidity risk as a key constraint experienced by emerging MFIs. Studies conducted by Asiama et al (2007) pointed out lack of management skills and poor supervision as some critical risk factors that cause failure in MFIs operations. Due to underlying economic and financial market factors which according to Mawuko-Yevugah (2013) brings about a decline in economic value, the market risk was identified as a critical risk factor which brings about such decline. Credit risk which is the risk associated with borrowers late and non-payment of loan obligations are one of the critical risk factors (gtz, 2000).

On the other hand, some of the drivers that sustained MFIs in Ghana are judicious risk management, skilled management, effective regulation, good corporate governance, liquidity, to mention a few. It is in light of the forgoing's that this paper seeks to demonstrate an existing relationship between risk factors and MFIs sustainability in Ghana.

The hypothesis carried out on various drivers of sustainability were upheld with a significant $\mathrm{p}$-value of 0.000 $<0.01 \mathrm{p}$ and concluded that all the drivers of sustainability identified have a significant effect on MFIs sustainability in Ghana. The path coefficient between risk factors and the drivers of MFIs sustainability establishes 
that risk factors have a significant effect on all drivers of microfinance institutions sustainability

The paper is structured into seven sections. Section one contains the introduction. Section two looks into drivers of sustainability in Microfinance operations. The study methodology is discussed in section three and section four discusses the analysis and hypothesis of the study. In section five is the implications of the study in terms of policy and was concluded in section six. Section seven is the reference.

\subsection{Drivers of sustainability in Microfinance Operations}

Risk management- The primary focus of risk management is making educated decisions about how much risk to tolerate, how to mitigate those that cannot be tolerated, and how to manage the real risks that are part of the MFIs business. However, since risk cannot be avoided or ignored in any financial transactions, there is the need for the institutions to effectively and efficiently manage their finances very well to be successful (Yegon et al., (2014). Poor management of risk by any MFIs will make the institutions not likely to be able to meet their social and financial objectives. Risk management is a challenging task for any MFIs, and it is becoming more important within a world of related economic events and financial systems. Financial institutions globally and regulators in the financial sector have classified risk management as a vital element of long-term success. Management and regulators now focus their ability to identify and manage future risks rather than concentrating on current or historical performance. Effective and on-time risk management benefits the institution's great gives management ample time for production and growth. It also allows MFIs to measure risk quantitatively and properly allocate capital and liquidity needs to curb the balance sheet risks faced by the institution and to evaluate the impact of potential shocks to the financial system or the institution (CGAP, 2009). Based on various arguments and studies put forward in risk management, we propose that risk management has a significant effect on MFIs sustainability in the following hypothesis:

$H_{R M}$. Risk management has a significant effect on MFIs sustainability.

Regulation-Regulatory administrators and other regulatory bodies are becoming increasingly interested in, and concerned about MFIs. However, some studies do not support the assertion that regulation is a sustainable factor and thus, there is a significant relationship between risk factors and MFIs regulation. D'Espallier et al. (2009), made it clear that even though regulation is part of the daily activity of MFIs, it holds back innovation in lending technology that has been the driving force behind MFIs' ability to expand outreach and serve poor clients. A research conducted by Cull et al. (2007) suggested that microfinance institutions which are subject to more rigorous and regular supervision are not less profitable compared to others despite the higher costs of supervision.

Nevertheless, a country's legal background and regulation principles according to Graff (2012), provides the basis that defines its financial development and economic growth, hence financial sector regulatory authorities such as the Bank of Ghana (BoG), the Finance Ministry and other supervisory agencies, who set out the rules for entry and exit of financial institutions and determines their limit for businesses and products, also specify criteria and standards for the sound and sustainable operation of the industry. Public funds deposited at financial institutions need to be protected and that is the primary reason for regulating and supervising MFIs. Thus, an independent third party such as the state or an agency is required to regulate and control the soundness of a country's financial institutions (Peprah, 2015). The banks and specialized deposit-taking institutions ACT, 2016 (ACT 930) gives the Bank of Ghana the mandate to license, regulate, promote and supervise non-banking financial institutions including MFIs.

Based on various arguments put forward in the above regulation review, we propose that regulation has an effect on MFIs sustainability in the following hypothesis:

$H_{R}$ Risk factors have a significant effect on microfinance regulation

Corporate governance-Yankah (2015) in his research outlines corporate governance as a structure which deals with the relationship between manager and shareholders and in particular the functioning of the boards of directors. The microfinance industry has been confronted with issues of corporate governance in the last two decades and has resulted in the collapse of several MFIs both in Ghana and beyond. (Ermann et al., 2002). The essence of corporate governance in MFIs is therefore weak and cannot have a significant effect on their sustainability. Larcker et al (2004) confirm this with inputs that some corporate governance characteristics show weak knowledge in interpreting some management decisions.

Notwithstanding the above inputs, governance is about achieving corporate goals, and the first goal of MFIs is to reach more clients in the poorer strata of the population, and the second goal is financial sustainability (Mersland and Strom, 2009). Further to their earlier submission, Mersland and Strom (2009) pointed out that problems of credit risk assessment and repayment make the governance of firm- customer interactions potentially more important in financial institutions than in other industries. Further to that, Mersland and Strom (2009) clarified that financial performance and MFIs sustainability improves with a strong corporate governance structure which is being advised by an internal auditor. Gompers et al. (2003) in their empirical research based on factors that influence shareholders rights finds a significant relationship between, sustainability and corporate governance. Bauer et al. (2004) also argue that good corporate governance will increase investor trust and reduces governance 
risk

Based on these studies put forward in the corporate governance review, we propose that MFIs sustainability can be depended on corporate governance in the following hypothesis:

$H_{C G}$. Corporate governance has a significant effect on microfinance sustainability.

Technology and innovation (IT)-The microfinance industry for the last decade has been marked by the increasing influence of Information Technology. Some researchers like Iyengar et al (2010) believed that the efficiency and capabilities of a microfinance institution may only be realized by combining it with technology.

However, most customers of MFIs are those without much formal education and also from the rural poor. These customers lack the ability to understand and comprehend the usage of the IT to transact business and thus withdrawn from doing business with MFIs (Budampati and Reddy, 2018).Performance and survival of MFIs in these areas cannot be supported by IT.

Nevertheless, there is increasing recognition of information technology (IT) potential in contributing to income generation and poverty reduction. MFIs understand the effect IT can have on every aspect of an institution's performance. As emphasized by Hishigsuren (2006), MFIs need to have an integrated and well-developed information system to handle their portfolio and other transactions, if they have to improve their performance and survive. Lack of technology has hampered most MFIs in their quest to reach a big proportion of the rural poor (Iyengar et al, 2010). Microfinance institutions in Ghana and beyond are having challenges increasing their growth rate due to poor data systems and the lack of infrastructure. To correct that effect, MFIs operators are coming out with new business practices and innovative ideas which are linked to technology with cost reduction to achieve the breakthrough in scale (Bhatt and Tang, 1998). Whilst some operators cannot fathom the real solutions confronting the microfinance sector, a section of them believed that connecting IT-based systems to their operations have the potential to have a positive impact in MFIs (De and Ratan, 2009).

Based on these studies put forward in the information technology review, we propose that MFIs sustainability can depend on information technology in the following hypothesis:

$H_{I T .}$ Information technology has a significant effect on microfinance sustainability.

Quality workforce/Training- Human resource, according to Dessler (2005) is the process of hiring and developing employees for the benefit of the organization. It is therefore clear that a change in management practices comes about as organizations improve the working force to increase efficiency and effectiveness.

However, most employees in MFIs in Ghana have low competency level which is below what is desired. This is due to the inability of the MFIs to attract and retain a high caliber of staff due to the poor condition of services resulting in high employee turnover (Boateng et al, 2014). This gives a clear indication that the workforce cannot play an active role in the sustainability of MFIs in Ghana.

Nevertheless and according to some studies conducted, good employee management through a continuous robust training play a vital role in enhancing MFIs with proven technical expertise in the field of operations (Ayayi et al, 2010). MFIs with well-trained employees who are motivated by financial incentives that include bonuses and other benefits are indispensable to attain financial sustainability (CGAP, 2009). According to McGrath et al, (1996) the basic asset that can have a positive impact on an organization's development is the depth of the working force. Ayayi et al, (2010) further made an input in their research on African businesses which also confirmed that organizational success can also depend on the workforce, their level of education and training. Staff with proven technical expertise in the field of microfinance is another prerequisite for the effective choice and monitoring of loans, deposits, and other financial projects. Boateng et al (2014) also made the assertion that the institutions with employees having a greater level of education and training are more able to adapt to business operations and changes in the business environment.

We propose that MFIs sustainability can depend on the quality of the workforce based on the review of the number of studies in the following hypothesis:

$H_{Q W}$ Quality of the workforce has a significant effect on microfinance sustainability.

Leadership and Management-Leadership are specific to the task and may be differences in required leadership styles at different levels in the same organization (Owens, 1995).MFIs are encouraged to recruit based on task and the company's ultimate goal. Jeremy, et al., 2012 define leadership styles as a process of influencing others to commit their full potential towards achieving shared vision with both passion and integrity.

However and according to Njue (2017) since micro financing is a social intervention policy it is more successful among members of the community because they know and trust each other, and thus it is easier for them to enforce repayment through social sanctions than it would be for an MFI manager or leader who is not a member of the community. A report from the USAID also indicates that in reality, most MFIs do not benefit from management/leadership which tends to be autocratic in style (USAID, 2006). This was further clarified by Kesper (2000) that most MFIs management are conversant with their institutions, but are regularly not able to identify all the factors affecting their organization success. Finally, not every leader can be a good one and thus, the success of MFIs does not largely depend on the leadership style (Bennett et al, 1995).

Jeremy, et al. (2012) on the other hand, explained that the strength of leadership influences and motivates 
each team member or employee to voluntary co-operate with each other to achieve the objectives set by the leader. Successful organizations are the result of effective leadership and also organizational culture. A research conducted by the Consultative Group to Assist the Poor (CGAP, 2009) indicates that MFIs needs modern and efficient employee management and strategy to allow them to control their operating costs. And according to Boateng et al, 2014, lack of management skill and training was primarily some of the MFIs failures in Ghana.

Based on various arguments and studies put forward in leadership/management, we propose that leadership/management has a significant effect on MFIs sustainability in the following hypothesis:

$H_{L M}$ Leadership/management has a significant effect on microfinance sustainability.

Access to Funds/Liquidity-Liquidity state of any financial institution, as noted by Jeanne and Svensson (2007), is a key determinant of the company's financial performance. Liquidity is the amount of capital that is accessible for investment and spending (Jeanne and Svensson, 2007). It describes the ability to easily convert assets to cash. Since cash is the most liquid asset due to its readiness and direct, MFI needs to keep some amount of liquid assets in times of crisis or emergency Chaplin et al (2000).

Ganka (2010) however argues that having structured capital different sources of capital do not improve financial sustainability. Moreover, inputs from various literature sources (Nair et al., 2010; Hayder, 2002; Bank of Ghana, 2007; Ghartey, 2007) have attributed failure in most MFIs within the first five years of operations to over trading and financial strain. In Ghana, access to a cheap source of finance for MFIs has been a challenge, with many resolving to deposits and investment with high-interest rates which makes their operations unsustainable. Perera et al., (2006) cautioned MFIs of extreme volatility in the capital market. This and many more indicate that sustainability of MFIs in Ghana does not largely depend on the institution's liquidity.

A number of studies conducted on microfinance also conclude that capital structure determines the sustainability of MFIs. According to Eljelly (2004), profitability and liquidity can be classified as good pointers to determine the strength and performance of any financial institution. Crowe (2009) mentioned that effective and efficient liquidity management supports a MFIs ability to meet cash flow obligations which are largely uncertain and controlled by external events factors.

Based on various inputs and studies put forward in liquidity/access to funds, we propose that liquidity/access to funds has a significant effect on MFIs sustainability in the following hypothesis:

$H_{L A F}$ Liquidity/Access to funds has a significant effect on microfinance sustainability.

Market Availability/Reach- A number of rural poor in Africa and elsewhere do not have access to formal financial services, which means that in Ghana, for instance, the large majority do not have access to secure and productive means of saving, safe and efficient ways of transacting money, or regulated credit. Microfinance institutions in Ghana and elsewhere in Africa are confronted with a number of challenges in an attempt to break new ground by offering banking services to such communities.

The tight economic background of this low-income clientele possesses a risk that credit might be used for general household expenditure that does not yield the expected returns or ability to repay (IFC, 2014). Woller and Schreiner (2002) cautioned MFIs on their research that small loans which are given to the poor and unstructured businesses are highly risky and associated with lower financial sustainability. Difficulties associated with reach/marketability and inputs from other studies indicate that MFIs in Ghana cannot have access to the poor and are not sustainable within the identified market. Outreach or the market cannot be a strong basis for MFIs sustainability

However, authors like Hishigsurem (2004), Mersland and Strom (2009) and later Kinde (2012) have argued that a larger number of borrowers determine the number of poor clients that can be reached and served. Hulme and Mosley (1996) still believed that microfinance services should be centred on the poor and that without the poor, MFIs is no longer different from the commercial banks.

Based on arguments from other studies put forward in marketability/reach we propose that MFIs has a market in Ghana and thus marketability/reach has a significant effect on MFIs sustainability in the following hypothesis: $H_{M / R}$ Marketability/Reach has a significant effect on microfinance sustainability.

\subsection{Relationship between risk and sustainability of MFIs operations}

Some researchers believed that loans with higher risks yield greater returns (Abdus, 2004) compared to those with lower risk. Thus the desire for MFIs to go for higher-risk in business decisions is likely to be greater because of the higher returns associated with it. According to Oberdorf (1999), risk levels should be in direct proportionality to the expected returns (Mawuko-Yevugah, 2013), thus MFIs which are able to manage these risks will be successful. If the risk is not managed well, MFIs w9ill likely fail to meet their social and financial objectives. A poorly managed risk results in financial losses, investors and donor confidence is affected and potential sources of funding will be lost (Mawuko-Yevugah, 2013). MFIs are therefore left to decide to operate with an appreciable level of risk which yields a greater profit to the institution. This observation as emphasized by Downes and Goodman (1995) is closely related to one conclusion of the Capital Assets Pricing Theory which states that risk and return are positively related. 


\subsection{Methodology}

The methodological positioning of this study, however, emanates from the positivist viewpoint in social research. The choice of positivism was based on a well- structured methodology that enables generalization and quantifiable observations to be analyzed statistically (Novikov and Novikov, 2013). The research employed non-probability sampling techniques. The non-probability (purposive sampling) was adopted to extract data from the MFIs. The study population was 277 MFIs in Accra. The adopted questionnaires were distributed to 100 MFIs out of the entire population through a simple non-random sampling. The simple approach was personnel from these institutions, like Managers, and Chief executive officers who are reliable and available to provide the relevant information needed for this study. 73 responded out of the 100 distributed. The questionnaire was made up of 26 questions grouped under three headings; critical risk factors, drivers of sustainability and relationship between risk and MFIs sustainability. The study adopted a quantitative research approach in data collection. This enabled the researcher to answer the research question and also meet the objective of the research as explained by the Saunders et al (2009). Modeling the relationship between risk and sustainability of MFIs in Ghana was done through a Partial Least Square Structural Equation Model (PLS-SEM). The frequency, mean and standard deviation were used to ascertain and assess the differences in respondent's opinions. The PLS-SEM was used instead of the regression covariance-based due to the sample size. According to Monecke and Leisch (2012), PLS-SEM offers a number of advantages over some more familiar methods and also provides a general framework for linear modeling.

\subsection{Analysis}

Table 4.1 investigates the risk factors affecting MFIs operations from an open-ended questionnaire. There were six major risk factors identified by respondents. Liquidity, Credit, Finance Management, Poor governance, Regulatory and Operation risk. Credit risk was rated the highest risk factor with a risk index of 0.81 . The range of index from 0.70-0.81 indicates that the risk factors selected by respondents have a strong effect on MFIs operations. Table 4.2 also highlights ratings of the drivers that sustain MFIs operations. Ten drivers were identified by respondents. Institutions liquidity was paramount and was rated highest with a driver's index of 0.86 and a standard deviation of 0.923 . Technology and Innovations were rated lowest with a drivers' index of 0.68 . The range of index for the drivers identified gives a clear indication that all of them have an effect on MFIs operations in Ghana. Table 4.3 shows the description of variables for both the risk factors and the drivers of sustainability.

Figure 1 showed the relationship between risk factors and microfinance institutions sustainability. The figure is known as path diagram demonstrating the link between the constructs; exogenous variable (risk factors) and the endogenous variable (MFIs Drivers of sustainability). The constructs were measured by means of reflective indicators approach. Table 4.4 showed the measurement model and the structural model of the Partial Least Square Structural Equation Model (PLS-SEM). The measurement model assessed the reliability and validity of the constructs. The internal consistency (composite reliability) and indicator reliability were used to assess the reliability of the model. Convergent validity (average variance extracted) and discriminant validity were used to assess the validity of the model. From the model measurement, the construct indicators outer loadings for risk factors were high 0.70 or higher except CRFMRF1 and CRFMRF3, and MFIs sustainability indicators were averagely higher, $>0.70$ which showed that the outer loadings were very satisfactory. The values of Average Variable Extraction (AVE) were higher than the conventional point of $0.5(50 \%)$ and therefore support convergent validity of the model.

\subsection{Analysis from Testable Hypothesis}

In Table 4.4 the Structural Model Assessment shows the effect of drivers of sustainability on MFIs operations with a significant $p$-value of $0.000<0.01$. We, therefore, reject the null hypothesis established and conclude that all the drivers of sustainability identified have a significant effect on MFIs operations in Ghana.

The path coefficient between risk factors and the drivers of MFIs sustainability was 0.582 with a significant pvalue of $0.000<0.01$. This established that risk factors have a significant effect on all drivers of microfinance institutions sustainability. This implies that a considerable risk on any MFIs drivers will have an adverse effect on their sustainability.

Table 4.1: Rating of the effect of risk factors on MFIs operation

\begin{tabular}{lccccc}
\hline & N & Mean & Std. Deviation & Risk Index & Rating Order \\
\hline Credit Risk & 73 & 4.06 & 1.026 & 0.81 & 1 \\
Liquidity Risk & 73 & 3.95 & 1.268 & 0.79 & 2 \\
Finance Management Risk & 73 & 3.85 & 1.009 & 0.77 & 3 \\
Poor Government Risk & 73 & 3.75 & 1.211 & 0.75 & 4 \\
Operation Risk & 73 & 3.48 & 0.973 & 0.70 & 5 \\
Regulatory Risk & 73 & 3.48 & 0.852 & 0.70 & 6 \\
\hline
\end{tabular}


Table 4.2: Drivers of sustainability to their effect on operations of MFIs

\begin{tabular}{llllll}
\hline & N & Mean & Std. Dev. & Drivers Index & Order of Sustainability \\
\hline Liquidity & 73 & 4.30 & 0.923 & 0.86 & 1 \\
Access Affordable Financing & 73 & 4.18 & 0.903 & 0.84 & 2 \\
Good Credit Appraisal & 73 & 4.01 & 0.874 & 0.80 & 3 \\
Good corporate governance & 73 & 3.89 & 1.062 & 0.78 & 4 \\
Skilled Management and Leader & 73 & 3.84 & 0.764 & 0.77 & 5 \\
Good Coverage & 73 & 3.67 & 0.851 & 0.73 & 6 \\
Staff Training and motivation & 73 & 3.66 & 0.837 & 0.73 & 7 \\
Judicious risk management system & 73 & 3.64 & 0.840 & 0.73 & 8 \\
Rigid Regulations & 73 & 3.59 & 0.779 & 0.72 & 9 \\
Technology and Innovations & 73 & 3.43 & 0.971 & 0.68 & 10 \\
\hline
\end{tabular}

Table 4.3: Description of Variables

\begin{tabular}{|l|l|}
\hline Variable Names/Constructs & \multicolumn{1}{l|}{ Label } \\
\hline Risk Factors & Operation Risk \\
\hline CRFMRF1 & Finance Management Risk \\
\hline CRFMRF2 & Regulatory Risk \\
\hline CRFMRF3 & Credit Risk \\
\hline CRFMRF4 & Liquidity Risk \\
\hline CRFMRF5 & Poor Government Risk \\
\hline CRFMRF6 & Staff Training and motivation \\
\hline Drivers of Sustainability to Effect Operations \\
\hline DRIVERSUS1 & Skilled Management and Leader \\
\hline DRIVERSUS2 & Rigid Regulations \\
\hline DRIVERSUS3 & Good Credit Appraisal \\
\hline DRIVERSUS4 & Liquidity \\
\hline DRIVERSUS5 & Access Affordable \\
\hline DRIVERSUS6 & Good Coverage \\
\hline DRIVERSUS7 & Judicious risk management system \\
\hline DRIVERSUS8 & Technology and Innovations \\
\hline DRIVERSUS9 & Good corporate governance \\
\hline DRIVERSUS10 &
\end{tabular}

Figure 1. Relationship between Risk Factors and Drivers of sustainability

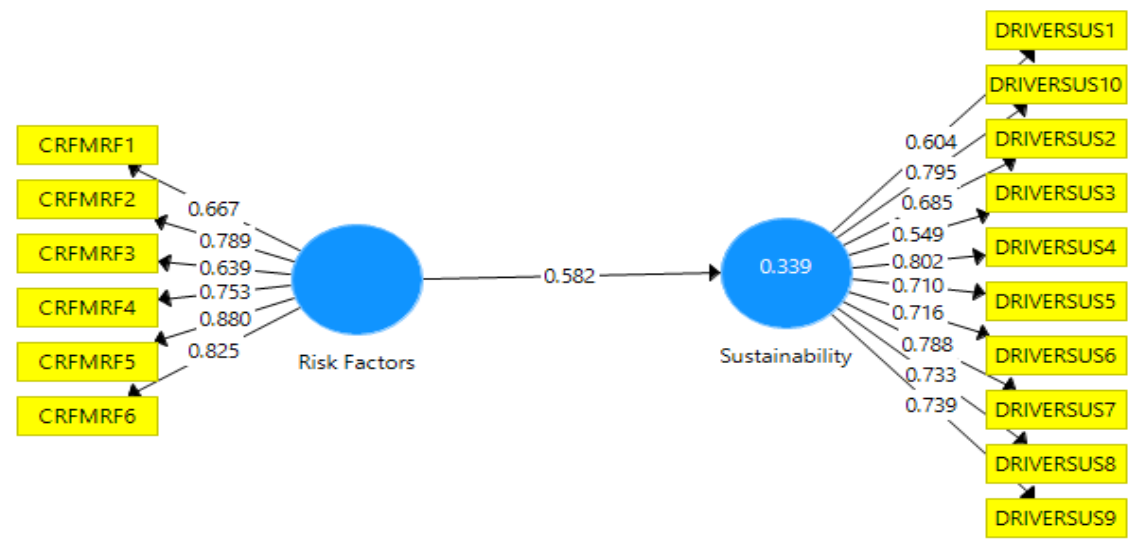


Table 4.4: Measurement Evaluation and Structural Model Results(Figure 1)

\begin{tabular}{|c|c|c|c|c|}
\hline Constructs/Indicators & Loadings & Composite Reliability & Cronbach's Alpha & AVE \\
\hline Effect of Risk Factors & & \multirow{7}{*}{0.892} & \multirow{7}{*}{0.856} & \multirow{7}{*}{0.583} \\
\hline$\overline{\text { CRFMRF1 }}$ & 0.667 & & & \\
\hline CRFMRF2 & 0.789 & & & \\
\hline CRFMRF3 & 0.639 & & & \\
\hline CRFMRF4 & 0.753 & & & \\
\hline CRFMRF5 & 0.880 & & & \\
\hline CRFMRF6 & 0.825 & & & \\
\hline \multicolumn{5}{|c|}{ Drivers of Sustainability to Effect Operations } \\
\hline DRIVERSUS1 & 0.604 & \multirow{10}{*}{0.912} & \multirow{10}{*}{0.898} & \multirow{10}{*}{0.513} \\
\hline DRIVERSUS2 & 0.689 & & & \\
\hline DRIVERSUS3 & 0.549 & & & \\
\hline DRIVERSUS4 & 0.802 & & & \\
\hline DRIVERSUS5 & 0.710 & & & \\
\hline DRIVERSUS6 & 0.716 & & & \\
\hline DRIVERSUS7 & 0.788 & & & \\
\hline DRIVERSUS8 & 0.733 & & & \\
\hline DRIVERSUS9 & 0.739 & & & \\
\hline DRIVERSUS10 & 0.795 & & & \\
\hline \multicolumn{5}{|c|}{ Structural Model Assessment of the Model } \\
\hline Endogenous Constructs & R-Square & & Q-Square & \\
\hline Sustainability & 0.339 & & 0.134 & \\
\hline Relation & Path Coefficient & P-value & Bias Corrected & o CI \\
\hline Risk Factors-Sustainability & 0.582 & 0.000 & 0.456 & 0.659 \\
\hline
\end{tabular}

5.0 Implications for policy and practice

The analysis from the study gives a clear indication that risk affects a major part of MFIs operations in Ghana. It establishes that risk factors have a significant effect on drivers of sustainability. It was also concluded from the above hypothesis that drivers of sustainability identified have a significant effect on MFIs operations in Ghana, thus a change in any driver can have a significant effect on the institution's sustainability. It is therefore recommended that MFIs in Ghana employ a thorough risk analysis on all their business operations so as to address any risk related issue pertaining to their operations. MFIs in Ghana should, as a matter of urgency design a risk manual or any risk framework to manage risk. The regulatory body, Bank of Ghana (BOG), must ensure that all existing MFIs comply with the internal risk policy and report regularly. BOG must ensure that approval of a new license should have a comprehensive risk policy or manual as a basic requirement.

\subsection{Conclusion}

Respondents identified Liquidity, Credit, Finance Management, Poor governance; Regulatory and Operation risk were identified as some of the major risk factors confronting MFIs in Ghana. Risk management, good corporate governance, regulation, effective leadership or management, liquidity were also some drivers of sustainability identified by respondents. With a significant $p$-value of $0.000<0.01 \mathrm{p}$, the various hypothesis were upheld and concluded that all the drivers of sustainability identified have a significant effect on MFIs sustainability in Ghana. The path coefficient between risk factors and the drivers of MFIs sustainability was 0.582 with a significant $\mathrm{p}$ value of $0.000<0.01$. This established that risk factors have a significant effect on all drivers of microfinance institutions sustainability. Also implies that a considerable risk on any MFIs drivers will have an effect on their sustainability supporting Abdus (2004) assertion that risk is associated with returns. To be sustainable and meet all its social and financial objectives, MFIs should be able to improve on its risk practices.

\section{References}

Abdus, S. (2004). Performance of Interest Free Islamic Banks: Vis-à-vis interest-basedconventional Banks of Bahrain. Journal of Economics and Management, 12 (2),115-129.

Asiama, P. and Osei, V., (2007).Microfinance in Ghana: An overview. ResearchDepartment, Aspects of Outreach. Journal of International Development, 14 (3), 301-304. Available at www.ifc.org/financialinclusionafrica

Ayayi, A., Sene, M. (2010). What Drives Microfinance Institution Financial Sustainability. The Journal of Developing Areas, 44(1), 303-324

Bank of Ghana, (2007). A Note on Microfinance in Ghana. Working Paper, Bank of Ghana Research Department. 
Bauer, R., Guenster, N., Otten, R. (2004). Empirical evidence on corporate governance in Europe: The effect on stock returns, firms value and performance. Journal of Asset Management.5 (2), 91-104

Bennett, N., Wise, C., Woods, P.A., Harvey, J.A (2003). Distributed Leadership, Nottingham: National College of School Leadership

Bhatt, N. and Tang, S. (1998). The Problem of Transaction Costs in Group-Based MicroLending: An Institutional Perspective, World Development, 26(4), 623-637

Boateng, A.A and Boateng.G.O. (2014).”An Appraisal of Risk Management Practices of Microfinance Institutions in Ghana". Journal of Economics and Sustainable Development. 5(6), 14-21

Budampati, V.S., Reddy, R. (2018). Impact of Information Technology on Microfinance Industry. Advanced Science and Technology Letters. 150, 161-121

Chaplin, G., Emblow, A. and Michael, I. (2000). Banking System Liquidity: Developments and Issues, Financial Stability Review, 6, 93-112.

Consultative Group to Assist the Poor (CGAP). Operational Risk Management for Microfinance Institutions. The World Bank, Washington DC, (2009)

Crowe, K. (2009). Liquidity risk management-more than ever. Harland Financial Solutions.3 (1), 1-5

Cull R., Demiguc-Kunt, A., Morduch, J. (2007). Financial Performance and Outreach: A Global Analysis of Leading Micro banks. Economics Journal. 117, 107-133

De, R., Ratan, A.L. (2009). Information Technology and Microfinance Institution:

Challenges and Lessons learned. Technology for development. 15(4), 259-282

Dessler, G (2005). Human Resource Management. $10^{\text {th }}$ Edition, Prentice Hall, Upper Saddle River.

D'Espallier, B., Guerin, I., Mersland, R. (2009): Women and Repayment in Microfinance. Rural Microfinance and Employment. Working Paper 2009(2).

Downes, J., Goodman, E. (1995). Finance and Investment Handbook. Baron's Educational .Education Efficient Financial Systems, 2015.

Eljelly, A. (2004). Liquidity-Profitability Trade off: Am Empirical Investigation in an Emerging Market. International. Journal of Commerce and Management, 14 (2), 48-61

Ermann, M.D., Lundman, R.J. (2002). Corporate and Governmental Deviance: Problems of organizational Behaviour in Contemporary Society. Oxford University Press, New York.

Fernando, N.A. (2008). Managing Microfinance Risk: Some Observation and Suggestions. Asian Development Bank.

Ganka, D. (2010), "Financial Sustainability of Rural Microfinance Institutions in Tanzania", Ph.D. Thesis, University of Greenwich, Australia.

Gesellschaft Fur Technische Zusammenarbeit (GTZ) GmbH (2000).A Risk Framework for Microfinance Institutions. Division 41 Financial System Development Banking Services.

Ghartey, G. (2007). Sustaining Microfinance in Ghana: Implications of both Prudential and Non-prudential Regulations for the Sub-sector, Paper presented at the annual Microfinance Conference, University of Cape Coast, Ghana.

Graff. (2012). Legal Origin and Financial Development: New Evidence and Old Claims. International Journal of Trade Economics and Finance, 3 (3)

Gompers, P.A., Ishii, J, L., Metrick, A. (2003).Corporate governance and equity prices. Quarterly Journal of Economics, 118(1), 107-155

Hayder, A. (2002). Micro Finance Associations: The Case of Ghana Micro Finance Institutions Network (GHAMFIN). Deutsche Gesellschaft für Technische Zusammenarbeit (GTZ) GmbH

Hishigsuren, G. (2006). Information and Communication Technology and Microfinance: Options for Mongolia. ADB Institute Discussion Paper 42.

Hulme, D., Mosley. (1996). Finance against Poverty; Routledge, London.

International Financial Corporation (IFC) (2014). The Partnership for Financial Inclusions: Who Are the Microfinance Clients?. A case study on Customer Segmentation and Product Development, Sub-Saharan African, Johannesburg

Iyengar, P.K., Quadri, N.A., Singh, V.K (2010). Information Technology and Institutions: Challenges and Lessons Learned. The Journal of Electronic Commerce in Organisations, 8 (2), 1-11

Jeanne, O., Svensson, L.O. (2007). Credible Commitment to Optimal Escape from a Liquidity Trap: The Role of the Balance Sheet. The American Economic Review, .97(1), 474-490

Jeremy, M., Melinde, C., Ciller, V. (2012). Perceived leadership style and employee participation in a manufacturing company in the Democratic Republic of Congo. African Journal of Business Management, 6 (15), 5389-5398

Kesper, A. (2000). Failing or not aiming to grow? Manufacturing Small Medium and Micro Sized Enterprise(SMME's) and their contribution to employment growth in South Africa. TIPS Working Paper15, Trade and Industrial Policy Strategies. Available:http://www.tips.org.za 
Kinde, B.A (2012). "Financial sustainability of microfinance institutions (MFIs) in Ethiopia". European Journal of Business and Management, 4(15), 1-8

Kibert, C.J., Thiele, L., Peterson, A., Monroe, M. (2012).The Ethics of Sustainability.Brundtland Report. Washington DC.

Labie, M., (2001) Corporate governance in microfinance organizations. A long and winding road. Management Decision, 39, 296-301

Larcker, D., Rusticus, T., Richardson, S. (2004).On the use of instrumental variables in accounting research. Working paper, University of Pennsylvania.

Ledgerwood J (1999). "Microfinance Handbook on Sustainable Banking with the Poor: An Institutional and Financial Perspective." The World Bank: Washington. D.C.

Mawuko-Yevugah, Y. (2013). "Banking the un-bankable: An empirical study of risk and risk management by microfinance institutions in Ghana. MSc. Thesis submitted to University of the Witwatersrand, Johannesburg

McGrath, R., Koch, M. (1996).Improving Labour Productivity: Human Resource microfinance institutions in Ghana". Journal of Economics and Sustainable Development, 5(6), 14-21

Mersland, R. and Strom, R.O. (2009). Performance and Governance in Microfinance Institutions. Journal of Banking and Finance, 33 (4), 662-669

Monecke, A., Leisch, F. (2012). SemPLS: Structural Equation Modelling using Partial Least Square. Journal of Statistical Software. 48(3)

Moore, P., G. (1970). The Theory of Risk. Journal of the Institute of Actuaries 96 (3)

Nair, A. and Fissha, A. (2010), Rural Banking: The Case of Rural and Community Banks in Ghana, Agriculture and Rural Discussion Paper 48, the International Bank for Reconstruction and Development: The World Bank, Washington D.C.

Njue, N.K. (2017).Influence of Leadership Development on the Performance of Microfinance Institutions in Kenya. (PhD Dissertation Jomo Kenyatta University of Agriculture and Technology, Kenya).

Novikov, A.M., Novikov, D.A. (2013). Research Methodology: From Philosophy of Science to Research Design. London N.Y. Leiden: CRC Press

Oberdorf, C. (1999). Microfinance: Conversations with the Experts. The United States of Organisational Behaviour in Contemporary Society. Oxford University Press, Oxford Organizations. Giordano Dell-Amore foundation. 24(4), 423-437

Owens, R.G. (1995).Organisational Behaviour in Education. $5^{\text {th }}$ edition, Allyn and Bacon, Participation in a manufacturing company in the Democratic Republic of Congo. African Journal of Business Management. 6 (15), 5389-5398

Peprah, J.A. (2015). Microfinance Regulation in Ghana: Missing Issues and Implications for Efficient Financial Systems. Asian Economic and Financial Review,June 2015.

Perera, S., Skully, M., Wickramanayake, J. (2006).Competition and structure of South Asian banking: A Revenue Behaviour Approach. Applied Financial Economics, 16, 789-801

Robinson, M., (2003).The microfinance revolution: Sustainable finance for the poor. Washington D.C: World Bank.

Saunders, M.N.K., Lewis, P. and Thornhill, A. (2009). Research Methods for Business Students. $4^{\text {th }}$ Edition. Financial Times Press.

USAID, 2006. Defeating Authoritarian Leaders in Post-Communist Countries. Results of a Cross-National Quantitative Study, Final Report, USAID 2006.

Uyemura, D. G., and Donald R. VD. (1993). Financial Risk Management in Banking: The Theory and Application of Asset and Liability Management. Bankline, Salem, Mass: Bank Administration Institute Foundation.

Woller, G., Schreiner, M. (2002). Poverty Lending, Financial Self-Sufficiency and the Six Aspects of Outreach. World Development, 31(9), 1567-1580

Yankah, N.K. (2015). Assessing Corporate Governance Practices in Selected Microfinance Institutions in Ghana. Master's Thesis submitted to Kwame Nkrumah University of Science and Technology, Ghana.

Yegon, C., Sang, J., Cheruiyot, P.K (2014). Effect of Financial Risk Management on Firm's Profitability; panel Data Econometrics of Selected Micro-Financial Institutions in Kenya. Research Journal of Finance and Accounting, 5 (9). 